\title{
Ethnomathematics: Predicting the Average Height of the Bali Mula Ancestors using Linear Regression
}

\author{
Jero Budi Darmayasa, 1,2, , Wahyudin ${ }^{2}$, Tatang Mulyana ${ }^{2}$ \\ ${ }^{1}$ Jurusan Pendidikan Matematika, FKIP Universitas Borneo Tarakan \\ Jl. Amal Lama No. 1 Tarakan, Kalimantan Utara \\ ${ }^{2}$ Departement Pendidikan Matematika, SPs Universitas Pendidikan Indonesia \\ Jl. Dr. Setiabudhi No. 229, Bandung 40154, Indonesia \\ ${ }^{*}$ Email: jeromath@student.upi.edu
}

Article received : February 2019, article revised : Agustus 2019, article published: September 2019

DOI : 10.25273/jipm.v8i1.3863

\begin{abstract}
The purpose of this study is to determine the average height of Bali Mula ancestors communities in the area of Ancient Caldera Batur. This research is a study of Ethnomathematics. In this case, we view Ethnomathematics as an intersection between mathematics, mathematical modelling, and cultural anthropology. We use exploration, observation, experimentation, documentation, and interviews method. In the initial stage of the study, we determine the relationship between the finger length index and the height body of Bali Mula male. The linear regression equation expresses the relationship, which is a length of the index finger as a predictor variable. Moreover, measure the pillars width of some houses Saka Roras and substituting it, we have the regression equation. Consequently, we estimate the average height of the Bali Mula ancestors in Kintamani area are $165 \mathrm{~cm}$. Since it contains linier regression concepts, prediction the average height of Bali Mula ancestors from their traditional homes may be used as the context in mathematical (statistical) learning at school or university.
\end{abstract}

Keywords: Ethnomathematics; Linear Regression; Bali Mula; Traditional House.

\section{INTRODUCTION}

Changes in various aspects of life will follow the change of time. An example is the development of technology. Basically, technological developments are clear evidence usefulness of science. In that case, mathematics contribute considerably. In addition to influencing the development of technology, mathematics it self is experiencing various advances (Grover \& Pea, 2013).

An expert namely August Comte stated that mathematics is not a science, but a logical thinking tool (Ngu, Hanafi, Taslikhan, \& Raman, 2016). Mathematics originally came from various cultures and can be a source of inspiration for students of their own (Lesser, 2006). Mathematics consists of two complementary subsets. First is a collection, or structure consisting of particular axioms, definitions, theorems, proofs, problems, and solution. This subset consists of all the instinctualized Ways of Understanding (WoU) in mathematics throughout history. Second, the subset consists of all the Ways of Thinking (WoT), which are characteristics of the mental acts whose products comprise the first set (Chiang \& Lin, 2007; Dündar, Temel, \& Gündüz, 2016; Kilpatrick, 2016). The three meanings show that mathematics is progressing. 
Tracking the development of mathematics does not necessarily lead to are interseted in studying the relationship of mathematics to anthropological culture. The practice of mathematics in society or in the form of community activity is known as Ethno mathematics (Mosimege \& Ismael, 2004).

Ethnomathematics practices can enrich mathematics curriculum in several ways: help students to understand abstract mathematics concepts (Owens, 2014), foster learning engagement (Verner, Massarwe, \& Bshouty, 2013), enhance motivation and positive attitude towards mathematics (Shirley, 2001), develop visuospatial reasoning abilities (Owens, 2015), reinforce problem solving skills (Amit \& Qouder, 2017; Jurdak, 2016), and creativity (D'Ambrosio \& D'Ambrosio, 2013; Massarwe, Verner, \& Bshouty, 2011).

The study of Ethnomathematics provides an opportunity to examine the application of mathematics in every aspect of community life in various parts of the world, not least on the island of Bali. As one of the favourite tourist destinations abroad, Bali is rich with culture. Like other cultures in other parts of the world, Balinese culture contains all the universal elements. The seven universal elements of culture include language, knowledge system, social organization, living equipment system and technology, livelihood system, religious system, and artistry.

As a cultural element, language is not exactly the same between one community group with another. The language between the Balinese community of Bali Mula, Bali Aga, and Bali Arya is not exactly the same, especially the dialectic. Bali Mula is a community that originally inhabited the island of Bali. Bali Aga is immigrants from modernization. In the last few years, many mathematicians and mathematical educators India who enter and settle in Bali. Bali Arya is Majapahit people who enter and settle in Bali. Another source mentioned that the Bali Aga is the first community in Bali.

Living equipment and technology systems, livelihood systems, and other cultural elements also experience differences among these communities (Adam, 2010; Cimen, 2014; Massarwe et al., 2011). For example, the traditional houses of the Community of Bali Mula in the Kintamani area are different from most houses in other areas of Bali. Saka Roras is the main house of Bali Mula in Kintamani area. As a traditional house, Saka Roras is part of the Culture of its people.

From the culture of society, we can trace the math application (Ascher, 1995; Verner et al., 2013). Consequently, we can browse math applications at Saka Roras's house. To find an average estimate of the ancestor's ancestral height, we can use a mix of mathematical applications and parts of Saka Roras's house. That is the novelty in this study. The previous studies didn't yet analysis about the ethnomathematics of Saka Roras's.

Knowing the height of the ancestor becomes important because of many questions from the current generation of Bali Mula about the history and its origin. There is the fact that many Balinese are trying to find their ancestral pedigree. Even some of them are switching after searching and keep looking.

Children often ask simple questions about the physical characteristics of their ancestors. They ask that question to the father, mother, grandparents, or the nearest person. It would be easy to answer or tell them if the ancestors in question have 
documentation in the form of photographs. However, photographs of the ancestors who lived before or until the 1970s in the Kintamani mountains are impossible. Unreachable geo-graphic factors make the inner villages of Batur Caldera become disadvantaged areas.

The information that children acquire related to the physical characteristics of their ancestors is often significantly different from one another. Knowing that the size of the index finger is the basis for making Saka Roras's house, it is possible to get more accurate information about the ancestor's height estimate. The discipline of the ancestors in keeping the tradition is a compelling reason that the houses they inherited and still stand today are built using sacred rules.

\section{METHODS}

This study used a mixed method. In practice, the study used Convergent parallel mixed methods (Ishtiaq, 2019). We collected quantitative and qualitative data simultaneously, then conducted a comprehensive analysis. The data collected relate to the traditional house of Saka Roras.

The community built and settle the traditional Saka Roras house in the Kintamani area spread over several villages. Most of the people of Bali Mula settle the villages of Songan, Belandingan, Pinggan, Terunyan and some surrounding villages. Therefore, in data collection requires several techniques to obtain optimal data.

We collect data by technique; Participant observation, in-depth interviews, material evidence and documentation, measurement (experiment). The use of detailed data collection techniques is as follows:
Table 1. Data Collection Technique

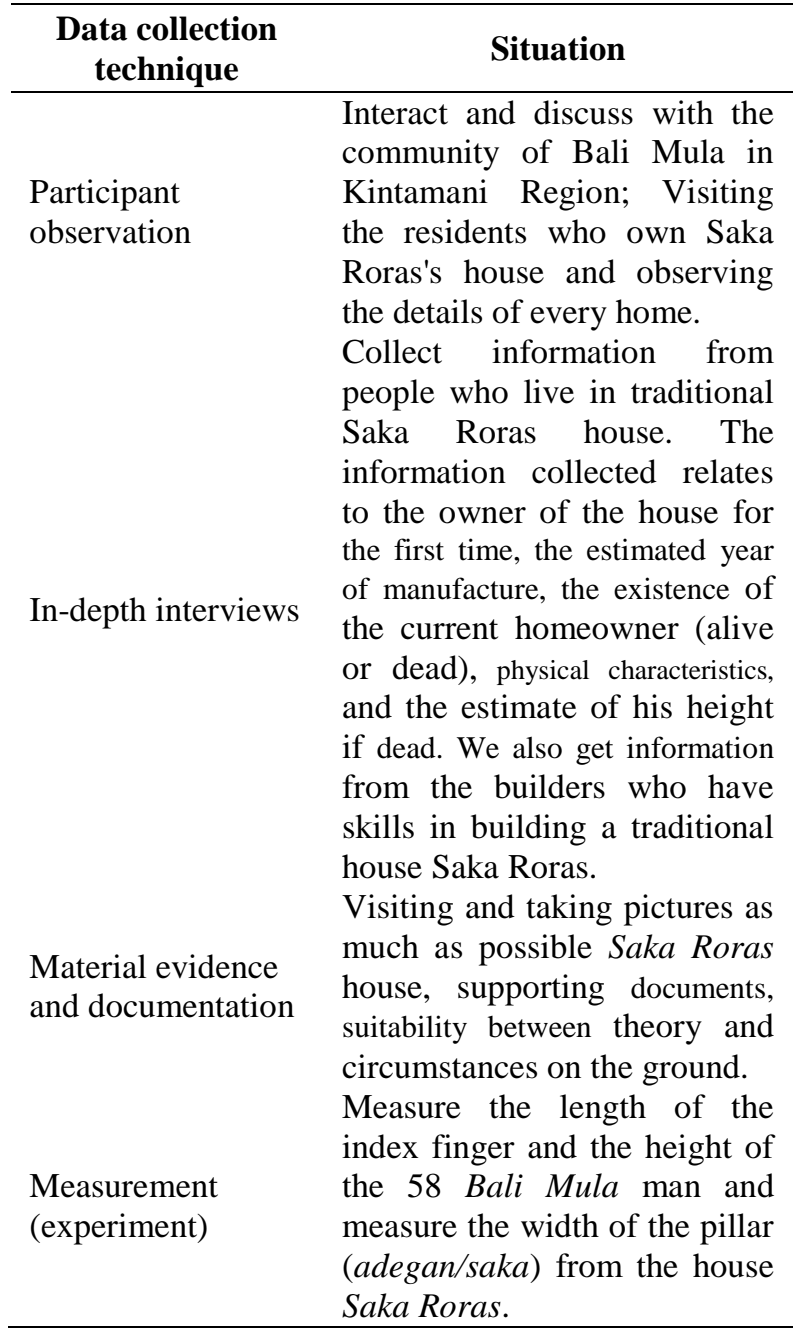

Sources of data and information sources in this study are the community of Bali Mula spread in several villages in the area of Batur Global Geopark in Kintamani District, Bangli, Bali. They are adult men, parents, builders (undagi), as well as the elders of Bali Mula.

\section{RESULT AND DISCUSSION}

The Community of Bali Mula was known as the Catur Sanak Residents. Catur Sanak includes Pasek Kayuselem, Pasek Celagi, Pasek Kayuan, and Pasek Trunyan. Pasek is naming for a community based on lineage or clan. Every citizen pasek has a place of worship together called Pura Kawitan. The four Pura Kawitan of Bali Mula residents is located in Ancient Batur Caldera Region. 
Pura Kawitan as a place of mutual worship is a building with detail and high aesthetic value. It is a characteristic of Balinese people who are obedient to tradition in various activities. So also in the construction of the house. One of the Balinese community's references in building houses and places of worship is a doctrine called Asta Kosalakosali. Asta Kosala-kosali is a combination of Asta Kosala and Asta Kosali. Asta Kosala is the name of Lontar (Book) about the size of making towers or tall buildings, containers, bade, stretcher. Meanwhile, Asta Kosali is the name Lontar (Book) about the size of making a house (Darmayasa, 2016).

Asta kosala-kosali as a source of knowledge contains some mathematical concepts and their application. The size of saka and the distance between buildings apply the concept of multiple linear regression. The size of the home yard applying the concept of multiplication and rectangle. For determining the length of the yard applies the concept of linear function. The number of likah and igaiga apply a modulo concept. The sizes on saka apply the concept of fractional and diagonal (Darmayasa, 2016). The builders (undagi) and most people follow strictly those measures. For example in the construction of a traditional house (Bale Saka Roras) for the community of Bali Mula in Kintamani Region. Saka Roras is a traditional house where the number of Saka (pillars) as many as 12 pieces. Here are the details of Saka Roras house:

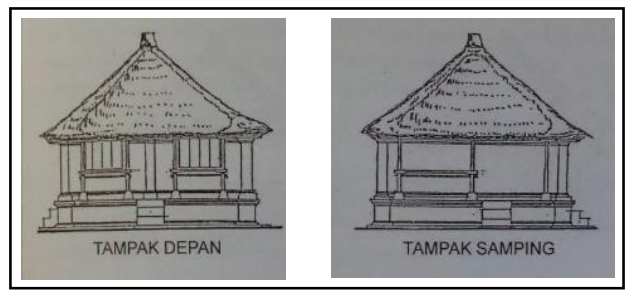

Figure 1. The shape of Bale Saka Roras

In fact, Saka Roras house model of Balinese society in Kintamani region varies. Between one village and another, there are some differences. Even in the same village, there are also differences in certain parts. Here are some models of Saka Roras houses that have been documented.

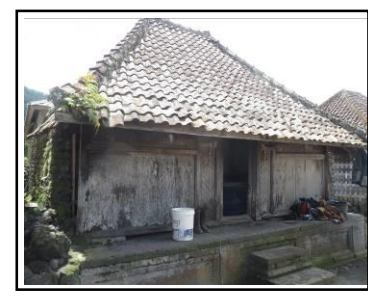

Figure 2. Home of Pasek Kayuselem Residents

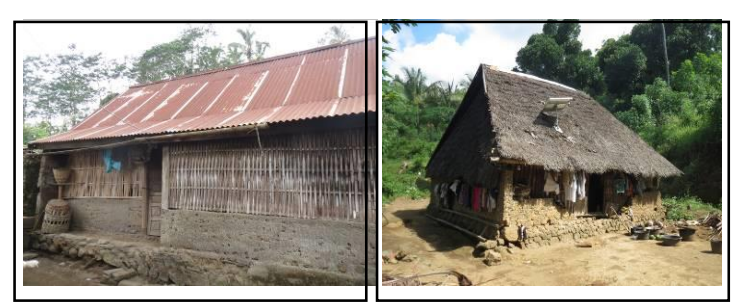

Figure 4. Home of Pasek Trunyan Residents

The making of traditional Balinese building structures is highly paying attention to details. Some part of the building's structure size depends on the size of body part from the head of family. Starting from determination length and width of yard and saka, the distance between saka, the number of iga-iga, and some other structures. Saka structure has very detail size. The homemaker sets the height and width of the saka, also the distance between the carvings and sculptures. The rules of the size came from the reason of rational and related to the magical aspect. The community believes if a measurement error occurs, it will have an impact on the economic and social life of the homeowner and his family.

The sizes of saka are substantial with the application of modern mathematics. 
Since traditional buildings are a universal element of cultural anthropology, the traditional Saka Roras house built by the Balinese community in Kintamani contains Ethnomathematics. In fact, by applying mathematical concepts and researching the size of the saka's width, Saka Roras traditional house can be used to find out the height of the home owner if he is dead. It is possible because the length of the index finger male who acts as the head of the family, determine the width of saka. A rai is the name for the length of the index finger. There are also other sizes of hands like a guli, a guli madu, anyari, duang nyari.

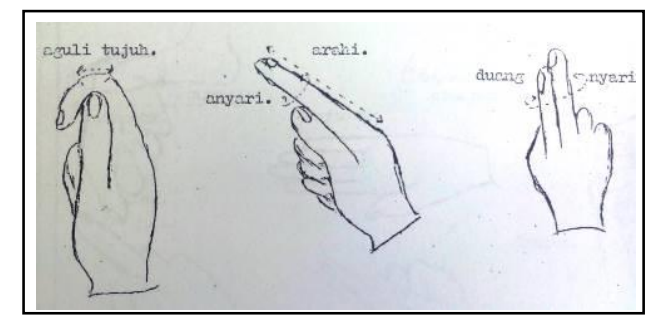

Figure 6. The size of the aguli tujuh, a rahi (a rai), a nyari, duang nyari.

The traditional house of Saka Roras from Bali Mula community in Kintamani area many inherited. This means it will be easy to determine the average estimate of the ancestral height of the Bali Mula community by knowing the size width of the house. As a first step, we make measurements of the index fingers and height of the men. From the measurement results, we obtained a relationship between the length of the index finger and the height of the body.

\section{Relationship of the index finger length with the height of the Body}

The index finger becomes the body part that is measured as it relates to the size of Saka's traditional house Saka Roras. The length of the index finger in Asta KosalaKosali is called a rai. A rai or a rai length of about $10 \mathrm{~cm}$. But it can be ascertained that the size of the rai for each person is different if measured accurately. The size of their height can also differently from each other with the measurement accuracy in centimetre units.

In theory, a rai is the length from the tip to the base of the index finger. Moreover, referring to the written text, measuring the bone segment on the outside of the index finger obtain the size of a rai. According to our observation, there is little difference between theory and application in society. From the interview with some elders of Bali Mula, there is an information that a rai is the distance from the tip of the index finger to the curve of the skin on the inside of the palm. The information from the community is in line with the fact that the width of Saka from Saka Roras' house is exactly the same as the length of the inside of index finger some resident.

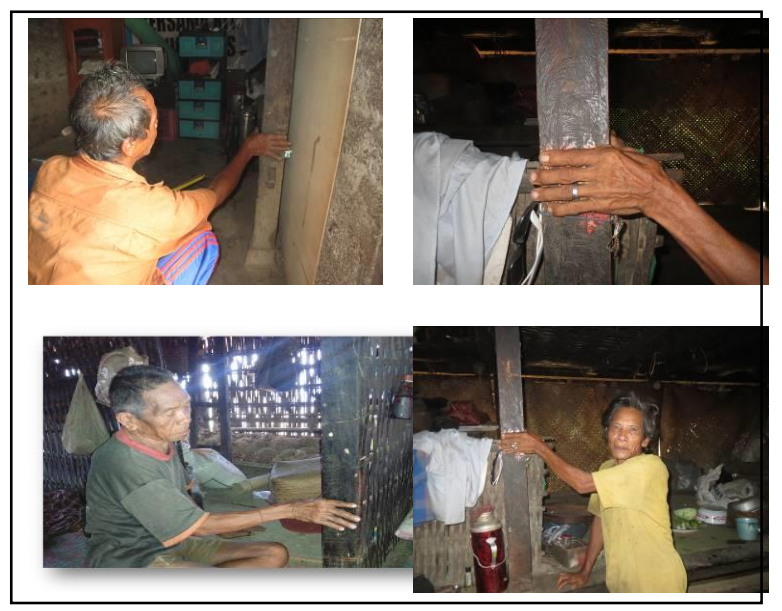

Figure 7. The width of the saka is equal to the length of the index finger

To determine the relationship between the length of the index finger with the height of the body from Bali Mula community, we measure 58 adult male people from the resident of Pasek Kayuselem, Pasek Celagi, Pasek Kayuan, and Pasek Terunyan. The results of analysis using SPSS 16.0. We 
obtain the relationship between the index finger length with height as follows:

$$
Y=10,544 X+70,428
$$

Where the height is $\mathrm{Y}$ and the length of the index finger is $\mathrm{X}$. The above equation shows that for every $1 \mathrm{~cm}$ in length increase on the index finger of the Bali Mula men then the height increases by $10,544 \mathrm{~cm}$. In addition, from the $F$-value of statistics it is known that there is a significant influence of predictor variables on dependent variables.

The length of the index finger affects the height of the body about $58.5 \%$. The relationship between two variables is strong, with the correlation coefficient is 0.765 . This means, the longer the index finger, the higher the person.

\section{Estimated Average height of Bali Mula's Ancestor}

The traditional house of the Bali Mula community in Kintamani is Saka Roras. It is made refer to the size of the body part from the head of the family that will settle the house. The width of saka depends on the length of the index finger. The height of saka depends on the length of the index finger and the finger joint or the width of the finger. The width of the door depends on the circumference of the head, and the width of the furnace mouth depends on the circumference of the lips.

Although in the making it depends on the head of the family, some of Saka Roras's houses can be inherited or traded. That fact makes it easy to find some old houses that are estimated to be over 80 years old. Based on interviews with builders and parents, they believe the houses are made with reference to the size of the original body part of the owner. Therefore, by measuring the width of saka, we will obtain the length of the index finger of the original owner of the house.

To estimate the average height of the ancestral of Bali Mula community in the area of Kintamani, we measure the width of saka from 42 houses of Saka Roras. The house is spread in four different villages, namely Songan A, Songan B, Terunyan, and Belandingan. From the results of measurement and using equation (1), we estimate that the height ancestral of the community in Kintamani area are as follows:

Table 2. Width of Saka from House of Saka Roras and Estimate of First Owner High Body

\begin{tabular}{|c|c|c|}
\hline No & $\begin{array}{l}\text { Width of } \\
\text { Saka }\end{array}$ & $\begin{array}{l}\text { Estimates of the First } \\
\text { Owner's Height Body }\end{array}$ \\
\hline 1 & 8.9 & 164.3 \\
\hline 2 & 9.0 & 165.3 \\
\hline 3 & 9.0 & 165.3 \\
\hline 4 & 9.2 & 167.4 \\
\hline 5 & 8.8 & 163.2 \\
\hline 6 & 8.8 & 163.2 \\
\hline 7 & 9.1 & 166.4 \\
\hline 8 & 8.9 & 164.3 \\
\hline 9 & 8.9 & 164.3 \\
\hline 10 & 8.8 & 163.2 \\
\hline 11 & 8.9 & 164.3 \\
\hline 12 & 9.0 & 165.3 \\
\hline 13 & 9.0 & 165.3 \\
\hline 14 & 8.8 & 163.2 \\
\hline 15 & 9.0 & 165.3 \\
\hline 16 & 9.0 & 165.3 \\
\hline 17 & 9.0 & 165.3 \\
\hline 18 & 9.1 & 166.4 \\
\hline 19 & 9.2 & 167.4 \\
\hline 20 & 8.8 & 163.2 \\
\hline 21 & 9.0 & 165.3 \\
\hline 22 & 8.8 & 163.2 \\
\hline 23 & 9.2 & 167.4 \\
\hline 24 & 9.1 & 166.4 \\
\hline 25 & 10.0 & 175.9 \\
\hline 26 & 8.8 & 163.2 \\
\hline 27 & 9.0 & 165.3 \\
\hline 28 & 8.8 & 163.2 \\
\hline 29 & 9.0 & 165.3 \\
\hline 30 & 9.7 & 172.7 \\
\hline 31 & 8.8 & 163.2 \\
\hline 32 & 9.1 & 166.4 \\
\hline 33 & 8.9 & 164.3 \\
\hline 34 & 8.4 & 159.0 \\
\hline 35 & 8.7 & 162.2 \\
\hline 36 & 8.6 & 161.1 \\
\hline 37 & 9.4 & 169.5 \\
\hline
\end{tabular}




\begin{tabular}{ccc}
\hline No & $\begin{array}{c}\text { Width of } \\
\text { Saka }\end{array}$ & $\begin{array}{c}\text { Estimates of the First } \\
\text { Owner's Height Body }\end{array}$ \\
\hline 38 & 9.5 & 170.6 \\
39 & 9.0 & 165.3 \\
40 & 8.8 & 163.2 \\
41 & 9.0 & 165.3 \\
42 & 8.7 & 162.2 \\
\hline
\end{tabular}

By substituting the size of the saka width into equation (1), we get an estimate of the height as shown in the table above. The average height of ancestral origin in the area of Kintamani is $165.2 \mathrm{~cm}$. It is the height of most men of ancestry in the region of Kintamani today.

\section{CONCLUSION}

The use of various data collection methods yields fairly accurate. Reading books of adaptations from the ancient lontar gives an overview of the rules in house building. Then

\section{REFERENCES}

Adam, N. A. (2010). Mutual interrogation: A methodological process in ethnomathematical research. Procedia Social and Behavioral Sciences, 8(5), 700707.

https://doi.org/10.1016/j.sbspro.2010.12.09 7

Amit, M., \& Qouder, F. A. (2017). Ethnomathematics and its Diverse Approaches for Mathematics Education. 23-51. https://doi.org/10.1007/978-3-31959220-6

Ascher, M. (1995). Models and Maps from the Marshall Islands: A Case in Ethnomathematics. Historia Mathematica, 22(4), 347-370. https://doi.org/10.1006/hmat.1995.1030

Chiang, H. M., \& Lin, Y. H. (2007). Mathematical ability of students with Asperger syndrome and high-functioning autism: A review of literature. Autism, 11(6), 547-556 https://doi.org/10.1177/1362361307083259 by visiting Saka Roras traditional house and interviewing the inhabitants, we obtained the history of the house and its size. From the results of measuring the length of the index finger and the height of the Bali Mula male, there is a relationship between them. Substituting the size of Saka's width from 42 Saka Roras houses, we get the average height of the first owner about $165.2 \mathrm{~cm}$. Since it contains linear regression concepts, prediction the average height of Bali Mula ancestors from their traditional homes may be used as the context in mathematical (statistical) learning at school or university.

Cimen, O. A. (2014). Discussing Ethnomathematics: Is Mathematics Culturally Dependent? Procedia - Social and Behavioral Sciences, 152, 523-528. https://doi.org/10.1016/j.sbspro.2014.09.21 5

D'Ambrosio, U., \& D'Ambrosio, B. S. (2013). The Role of Ethnomathematics in Curricular Leadership in Mathematics Education. Journal of Mathematics Education at Teachers College, 4, 19-25.

Darmayasa, J. B. (2016). Eksplorasi Ethnomathematics dalam Ajaran Asta Kosala-Kosali untuk Memperkaya Khasanah Pendidikan Matematika. Prosiding Seminar Nasional MIPA 2016, 17.

Dündar, S., Temel, H., \& Gündüz, N. (2016). Development of a mathematical ability test: a validity and reliability study. International Journal of Mathematical Education in Science and Technology, 47(7), 1061-1075. https://doi.org/10.1080/0020739X.2016.115 3734 
Grover, S., \& Pea, R. (2013). Educational Researcher. https://doi.org/10.3102/0013189X12463051

Ishtiaq, M. (2019). Book Review Creswell, J. W. (2014). Research Design: Qualitative, Quantitative and Mixed Methods Approaches (4th ed.). Thousand Oaks, CA: Sage. English Language Teaching, 12(5), 40. https://doi.org/10.5539/elt.v12n5p40

Jurdak, M. (2016). Learning and teaching real world problem solving in school mathematics: A multiple-perspective framework for crossing the boundary. Learning and Teaching Real World Problem Solving in School Mathematics: A Multiple-Perspective Framework for Crossing the Boundary, 1-199. https://doi.org/10.1007/978-3-319-08204-2

Kilpatrick, J. (2016). Reformulating: Approaching mathematical problem solving as inquiry. In Posing and Solving Mathematical Problems: Advances and New Perspectives. https://doi.org/10.1007/978-3-319-28023-3

Lesser, L. M. (2006). Book of Numbers: Exploring Jewish Mathematics and Culture at a Jewish High School. The Journal of Mathematics and Culture, 6(1), 8-31. https://doi.org/10.1192/bjp.111.479.1009-a

Massarwe, K., Verner, I. M., \& Bshouty, D. B. (2011). The Elements of Creativity and Giftedness in Mathematics. The Elements of Creativity and Giftedness in Mathematics, (January). https://doi.org/10.1007/978-946091-439-3
Mosimege, M., \& Ismael, A. (2004). Ethnomathematical studies on indigenous games: examples from Southern Africa. Icme-10, 14, 107-118. Retrieved from http://www.dm.unipi.it/ favilli/Ethnomathe matics_Proceedings_ICME10.pdf\#page $=12$ 3

Ngu, L., Hanafi, Z., Taslikhan, M., \& Raman, A. (2016). Influence of emotional intelligence on students' academic achievements. International Journal of Humanities and Social Science Research, 2(3), 41-46.

Owens, K. (2014). The impact of a teacher education culture-based project on identity as a mathematically thinking teacher. AsiaPacific Journal of Teacher Education, 42(2), 186-207. https://doi.org/10.1080/1359866X.2014.892 568

Owens, K. (2015). An Ecocultural Perspective on Visuospatial Reasoning in Geometry and Measurement Education. In Visuospatial Reasoning. Springer International Publishing.

Shirley, L. (2001). Ethnomathematics as a fundamental of instructional methodology. ZDM - International Journal on Mathematics Education, 33(3), 85-87. https://doi.org/10.1007/BF02655699

Verner, I., Massarwe, K., \& Bshouty, D. (2013). Constructs of engagement emerging in an ethnomathematically-based teacher education course. Journal of Mathematical Behavior, 32(3), 494-507. https://doi.org/10.1016/j.jmathb.2013.06.00 2 